\title{
Publisher Correction: The cooperative action of CSB, CSA, and UVSSA target TFIIH to DNA damage-stalled RNA polymerase II
}

Yana van der Weegen (D), Hadar Golan-Berman, Tycho E. T. Mevissen (D), Katja Apelt, Román González-Prieto (D), Joachim Goedhart (1), Elisheva E. Heilbrun, Alfred C. O. Vertegaal, Diana van den Heuvel, Johannes C. Walter (D), Sheera Adar \& Martijn S. Luijsterburg (i)

Correction to: Nature Communications https://doi.org/10.1038/s41467-020-15903-8, published online 30 April 2020.

The original version of this Article contained an error in the hyperlink to an interactive volcano plot for Figure 5 panel b (GFP-UVSSA vs GFP-UVSSA $\pm \underline{\mathrm{UV}}$ ). This has been corrected in both the PDF and HTML versions of the Article.

Published online: 06 November 2020

(c) (i) Open Access This article is licensed under a Creative Commons Attribution 4.0 International License, which permits use, sharing, adaptation, distribution and reproduction in any medium or format, as long as you give appropriate credit to the original author(s) and the source, provide a link to the Creative Commons license, and indicate if changes were made. The images or other third party material in this article are included in the article's Creative Commons license, unless indicated otherwise in a credit line to the material. If material is not included in the article's Creative Commons license and your intended use is not permitted by statutory regulation or exceeds the permitted use, you will need to obtain permission directly from the copyright holder. To view a copy of this license, visit http://creativecommons.org/licenses/by/4.0/.

(c) The Author(s) 2020 